\author{
Violetta Wróblewska* \\ Uniwersytet Mikołaja Kopernika w Toruniu \\ https://orcid.org/0000-0002-5776-8382
}

\title{
Ludowe bajki łotewskie w badaniach polskich folklorystów (rekonesans)
}

Streszczenie: Celem artykułu jest przegląd polskich badań folklorystycznych poświęconych łotewskim bajkom ludowym. Zasadnicza teza sprowadza się do uznania tych badań za marginalne, o czym świadczy nieznaczna liczba prac na ten temat od XIX do XXI wieku, na co wpływ mogło mieć kilka czynników. Wśród najistotniejszych wymienić można powody polityczne - złożone dzieje narodów polskiego i łotewskiego, kulturowe - nikła znajomość języka łotewskiego, utrudniająca kontakt $z$ oryginalnymi tekstowymi wytworami kultury, rzadko też tłumaczonymi na język polski, do tego nieduże zainteresowanie folklorem wynikające ze zwrotu ku masowej kulturze amerykańskiej.

Słowa-klucze: bajka ludowa, Łotwa, Polska, folklorystyka.

\section{Latvian folk tales in studies on Polish folklore (an Overview)}

Summary: The aim of the article is to review Polish folklore research devoted to Latvian folk tales. The main thesis comes down to considering this

Violetta Wróblewska - dr hab., profesor w Instytucie Nauk o Kulturze Uniwersytetu Mikołaja Kopernika w Toruniu. Jej zainteresowania badawcze obejmują folklor tradycyjny i współczesny oraz kulturę i literaturę dziecięco-młodzieżową. Jest redaktorką trzytomowego Stownika polskiej bajki ludowej (2018) oraz autorką wielu artykułów i prac monograficznych. Kontakt:viola@umk.pl 
research as marginal, as evidenced by a small number of works on this issue from the $19^{\text {th }}$ to the $21^{\text {st }}$ century, which may have been influenced by several factors. Among the most important reasons are political - complex history of Polish and Latvian nations, cultural - poor knowledge of the Latvian language hindering contact with original textual works of culture, rarely translated into Polish, and also scant interest in folklore resulting from the turn towards mass American culture.

Key words: folk tale, Latvia, Poland, folklore.

Zwrot Polaków w stronę ludowych bajek łotewskich nastąpił w XIX wieku na fali wzrastającego zainteresowania folklorem innych narodów, zwłaszcza tych, które szukały swej tożsamości i walczyły o niezależność. Wśród nich znaleźli się nie tylko Litwini czy Ukraińcy, ale także pozostający gdzieś na marginesie polskich badań Łotysze. Na temat ich dziejów i kultury nie pisano wiele, tak jest zresztą do tej pory, ale materiały różnego typu, w tym przekazy ludowe, w miarę regularnie były publikowane lub odnotowywane w polskojęzycznych czasopismach. W XIX-wiecznej prasie zamieszczano recenzje i omówienia wybranych zbiorów folkloru, chociaż nieliczne teksty odnosiły się bezpośrednio do łotewskich bajek, czy szerzej - oralnych opowieści. Zazwyczaj były to jedynie adnotacje dotyczące wydania zbioru ludowych przekazów, niekiedy także krótkie charakterystyki ich zawartości, na przykład:

Sbornikb materiulovb po etnografii, izdavaemyj pri Daškovskomb etnografičeskoms muzeé. Część II (pod redakcją W. Millera). Moskwa. 1887.

Spory tom ten zawiera 148 bajek łotewskich, zgromadzonych i przełożonych na język wielkoruski przez Briwzemnjaksa (właściwie Treulanda), którego znamy jako autora licznych zbiorów rzeczy ludowych łotewskich: pieśni, przysłów, zagadek, zamawiań, obrzędów i zwyczajów ${ }^{1}$. 
Warto podkreślić, że w tego typu pracach nie uwzględniano zróżnicowania etnicznego i regionalnego samej Łotwy, co wiązało się z nieznaczną wiedzą na temat tego kraju. Nie było mowy o wschodniej jego części - Łatgalii, do której głównie odnosiły się zbierane i publikowane materiały ludowe, wszystkie do dziś nazywane łotewskimi². O nikłej znajomości łotewskiej kultury przez Polaków pisała już w 1891 roku jej propagatorka i zbieraczka - Stefania Ulanowska:

Są ludy i okolice, nad któremi, zdaje się, że klątwa jakaś zawisła: świat się niemi nie interesuje, nic o nich nie wie i ostatecznie zapomina o ich istnieniu. Tak się do niedawna jeszcze działo z Kaszubami, tak się do dnia dzisiejszego dzieje z ludem łotewskim zamieszkującym nasze polskie Inflanty, któremu ani etnografija, ani lingwistyka żadnej dotąd kartki nie poświeciła. Co gorsza, że na miejscu, wśród tak zwanej „inteligencji”, krąży mniemanie, że łotysze nie mają ani literatury, ani gramatyki! Mniemanie niedorzeczne - faktem jest bowiem niezaprzeczonym, że u łotyszów są własne przysłowia, są piosnki starodawne i nowożytne, są bajki i opowiastki, są podania i cudowne wierzenia mitologiczne, - a więc jest owszem wszystko, co stanowi rodzimą ustną literaturę 3 .

Nie tylko w prasie XIX wieku rzadko pojawiały się publikacje o łotewskich bajkach ludowych, równie sporadycznie można odnaleźć informacje na ten temat $\mathrm{w}$ innego typu polskojęzycznych publikacjach pochodzących $\mathrm{z}$ tego okresu. Najczęściej bywają przywołane na zasadzie wzmianki, zwykle jako przykład analogicznego zjawiska występującego w folklorze innych narodów. Z takim ciekawym przypadkiem mamy do czynienia między innymi w Wielkiej encyklopedyi powszechnej ilustrowanej, t. 17-18, z 1896 roku, gdzie w bardzo obszernym haśle Dusza wskazano na podobieństwo wierzeń występujących w oralnych opowieściach polskich i łotewskich:

2 Zob. na ten temat: D. Rembiszewska, XIX-wieczne badania ludoznawcze na obszarze Łotwy w świetle korespondencji Stefanii Ulanowskiej do Jana Karlowicza, „Acta Baltico-Slavica" 2014, t. 38, s. 102-103.

3 S. Ulanowska, Łotysze Inflant Polskich a w szczególności gminy wielońskiej, powiatu rzeżyckiego: obraz etnograficzny, „Zbiór Wiadomości do Antropologii Krajowej” 1891, t. 15, cz. 1, s. 181. Zachowano we wszystkich cytatach oryginalną pisownię. 
Ludy Ameryki południowej wierzą w możność „nadmuchania”, tj. używotnienia tchnieniem na przykład sęp i strzał zrobienia z nich ludzi; ze zdziwieniem znajdujemy i u nas ślady wierzeń podobnych, na przykład w bajce o Lipieńskim, co to powstał z kawałka lipy, obrobionego przez stolarza, umalowanego przez malarza, a nauczonego „gadać, chodzić i pacierza mówić" przez parobka (Chełchowski Powieści I, 130-138; coś podobnego w bajkach łotewskich W. Weryhy nr XIII) ${ }^{4}$.

Na tym tle korzystnie prezentuje się bardzo dobrze dziś znana i opisana, między innymi przez Andrzeja Rataja ${ }^{5}$, trzyczęściowa publikacja wspomnianej Ulanowskiej pod tytułem Łotysze Inflant Polskich a w szczególności gminy wielońskiej, powiatu rzeżyckiego: obraz etnograficzny ${ }^{6}$. Praca ukazała się w latach 1891, 1892 i 1895 na łamach czasopisma „Zbiór Wiadomości do Antropologii Krajowej" (w tomach 15, 16, 18), a następnie funkcjonowała w obiegu w postaci odrębnych odbitek. Dzięki niej dotarły do polskich czytelników liczne informacje na temat łotewskiej kultury ludowej, jak też same ustne przekazy. W trzeciej części pracy znalazły się bajki we wszystkich odmianach - łącznie 53 opowieści i 22 formy krótsze, zwane przez etnografkę fraszkami , odnotowane w późniejszej systematyce wątków przez Juliana Krzyżanowskiego jako przykłady opowieści pozostających w związkach z polskim folklorem.

Waga publikacji o Inflantach, dziś pozostająca gdzieś na marginesie rodzimych dociekań folklorystycznych, a wysoko ceniona przez Łotyszy ${ }^{8}$, wynika z kilku powodów. Za najważniejszy można uznać ten, że Ulanowska samodzielnie zbierała materiały w terenie, spisywała teksty i je tłumaczyła, podając w druku obie językowe wersje, choć rzadko kiedy uwzględniała kontekst wykonawczy, a i jej wiedza na temat miejscowej kultury była wtedy nieznacz-

4 [b.a.], Dusza, [hasło w:] Wielka encyklopedya powszechna ilustrowana, red. Sz. Askenazy, t. 17-18, Warszawa 1896, s. 364.

5 A. Rataj, Stefania Ulanowska. Tajemniczy życiorys. Niepublikowane fragmenty twórczości, Białystok 2016.

6 S. Ulanowska, Łotysze Inflant Polskich a w szczególności gminy wielońskiej, powiatu rzeżyckiego: obraz etnograficzny, s. 181-282.

7 A. Rataj, dz. cyt., s. 55.

8 W 2011 roku wydano ją po łotewsku. Zob. A. Rataj, dz. cyt., s. 55.

9 Pisała na ten temat badaczka jej spuścizny - wspomniana już Rembiszewska, XIX-wieczne badania ludoznawcze..., s. 98-107. 
na9 . Niektórzy z ówczesnych mieli Ulanowskiej za złe nie tylko niedoróbki etnograficzne oraz językowe zebranych i wydanych przez nią narracji. Ostrym krytykiem okazał się zwłaszcza Gustaw Manteuffe ${ }^{10}$, znany badacz pieśni łotewskich ${ }^{11}$, zarzucający jej brak znajomości materiału i prac niemieckojęzycznych o kulturze ludu łotewskiego ${ }^{12}$. W odniesieniu do zapisanych opowieści oskarżał etnografkę o manipulację i niewiedzę, a nawet nieobyczajność:

W obszernych opisach obyczajów Łotwy naszej polsko-inflanckiej, przez tegoż uczonego wydawanych (Edwarda Woltera - V.W.), nie napotykamy nigdzie ani cienia zdrożności przytaczanych co chwila przez p. Ulanowską. Rozmija się tu autorka często z prawdą, pragnąc oczywiście urozmaicić swoję pracę w sposób niezwyczajny. Noszenie medalików i krzyżyków pod podeszwą w celu zabezpieczenia się od złodziejów (str. 261), a hostyj konsekrowanych umieszczanych pod piętą myśliwych dla pewniejszego strzału i trafiania w zwierzynę (str. 240), przytacza szan. autorka w rzekomo autentycznych klechdach łotewskich bez najmniejszego wahania, powyciągawszy te wiadomostki z mętnych źródeł, podawanych jej zbyt pochopnie przez wiedźmy małomiejskie wielońskiej osady fabrycznej, z najrozmaitszych narodowości złożonej. „Hostye” są żywcem wyjęte z powszechnie znanej legendy francuskiej, traktującej o człowieku pragnącym zdobyć tym sposobem władzę nadprzyrodzoną. Znieważanie krzyżyków i medalików należy do wszelkich podań europejskich, do których wchodzą czarownice, mające do czynienia z siłą nieczystą, a klechda o śmierci (str. 256) jest nieudolnem odbiciem powszechnie znanej gadki ludowej góralskiej, tak udatnie i z prawdziwym wdziękiem włożonej w usta Sabały przez Henryka Sienkiewicza ${ }^{13}$.

Zwłaszcza z zarzutem nieobyczajności trudno się zgodzić, biorąc pod uwagę fakt, że w tradycji ludowej wielu narodów odnotowywano teksty fry-

10 Jego rec. w „Kwartalniku Historycznym” 1892, t. 6, s. 591-601.

11 H. Kapełuś, Folklor obcy w badaniach Polaków, [w:] Dzieje folklorystyki polskiej 1864-1918, red. H. Kapełuś, J. Krzyżanowski, Warszawa 1982, s. 591.

12 G. Manteuffel, Ulanowska Stefania: Łotysze Inflant polskich, a w szczególności z gminy wielońskiej powiatu rzeżyckiego, obraz etnograficzny. Zbiór wiad. do antropologii krajowej, t. XV, str. 181-282. Kraków 1891. s. 591-592, „Kwartalnik Historyczny” 1892, t. 6, s. 591-601.

13 Tamże, s. 599. 
wolne, niekiedy nawet wulgarne, takie jak przyśpiewki i humoreski ${ }^{14}$. W tym zakresie Ulanowska wykazała się znacznym zrozumieniem tematyki, unikając typowego wśród wydawców i redaktorów tego czasu manipulowania zapisem, aby czytelnikom przedstawić treść artystycznie dopracowaną, wygładzoną i akceptowalną pod względem moralnym, czego zwolennikiem był Manteuffel. Zresztą sama etnografka w liście z 28 grudnia 1889 roku adresowanym do Karłowicza pisała o rzetelnym podejściu do pracy nad ludowymi tekstami, które ją fascynowały: „Z bajkami istna pociecha - są tu wszystkie rodzaje, jakie gdziekolwiek słyszałam i doskonale zbudowane”"15, a w kolejnym „część ostatnią, to jest bajki, spisane dosłownie z ustnego opowiadania, kończę już przepisywać na czysto"16.

Inni ówcześni krytykowali Ulanowską, warto dodać, że nie ją jedną, za to, że zajmuje się obcą kulturą, jej zbieraniem i utrwalaniem, a nie poświęca uwagi kulturze polskiej ${ }^{17}$, co należy również uznać za zarzut bezpodstawny. Etnografka posiadała już na swym koncie publikacje dotyczące kultury mazowieckiej, folkloru krakowskiego, góralskiego ${ }^{18}$, a ponadto, pisząc na temat ludu łotewskiego, brała pod uwagę część Inflant traktowaną jako integralny obszar Rzeczypospolitej, o czym świadczy fragment ze słowa wstępnego do pierwszej części jej pracy o Łotyszach: „lud łotewski zamieszkujący nasze polskie Inflanty"19. Ulanowska uznawała tego typu rodzaj zbierackiej i wydawniczej działalności za niezwykle ważny, czego dowodzą jej listy między innymi do Jana Karłowicza, a o czym wspominali Rataj20 i Rembiszewska, charakteryzując korespondencję obojga etnografów ${ }^{21}$. Karłowicz okazał się zresztą wielkim zwolennikiem i inicjatorem wielu tego typu badań oraz

14 Zob. D. Wężowicz-Ziółkowska, Miłość ludowa. Wzory miłości wieśniaczej w polskiej pieśni ludowej XVIII-XX wieku, Wrocław 1991; L. Podziewska, Ludowe opowiadania komiczne. Poetyka i antropologia, Wrocław 2010.

15 S. Ulanowska, List $n r$ 8, [w:] A. Rataj, dz. cyt., s. 124.

16 S. Ulanowska, List nr 18, [w:] A. Rataj, dz. cyt., s. 139.

17 H. Kapełuś, dz. cyt., s. 590.

18 Tamże, s. 591.

19 Z. Ulanowska, Łotysze Inflant ..., s. 181.

20 A. Rataj, dz. cyt., s. 26-27.

21 D. Rembiszewska, dz. cyt., s. 101-102. 
publikacji. Sam wysoko oceniał osiągniecie Ulanowskiej, czemu dał wyraz w „Bibliotece Warszawskiej”, prezentując szczegółowe omówienie studium o Inflantach. Wykazał w nim autentyczność pozyskanego przez etnografkę materiału, a także jego unikatowość:

Wiara w skarby zaklęte i czary, tak samo, jak u naszego ludu, płodzi liczne opowieści i strachy: jak w każdej mitologii, tak i w łotewskiej, zjawiska przyrody odbijają się w świadomości ludzkiej pod właściwym człowiekowi pierwotnemu kątem. Więc plamy na księżycu są widmem umieszczonej tam za karę dziewczyny z wiadrami: kret był dawniej człowiekiem, który nie chciał z innemi budować dróg i za to został ryjącem się wiecznie w ziemi zwierzątkiem; niedźwiedź był młynarzem, który się odważył straszyć pana Boga, a Świnia Żydówką, która nie wierzyła we wszechwiedzę pana Jezusa; znamy zresztą gadki te i z ust ludu polskiego. 0 kukułce Łotysze opowiadają bardzo ciekawą legendę, podobną nieco do "Malin” naszych (86). Również zajmującem jest podanie o początku krów i żołny (88). Zabawnem jest podanie o raku: „Gdy pan Bóg kazał zwierzętom kopać rzeki, to wszystkie przyszły na rozkaz i rak także; ale pan Bóg, chcąc sobie zażartować z niego, udał, że go nie widzi i powiada: »A gdzież to rak? « Rak okropnie się rozgniewał; »Cóż to, powiada, czy masz w tyle oczy, że mnie nie widzisz? «... Pan Bóg za zuchwalstwo zrobił mu tak, że sam ma teraz oczy nie z przodu" (89). Wiara w picie mleka przez węże i gadki o tem krążą wśród Łotyszów, jak i wszędzie prawie u nas $(90)^{22}$.

Przy okazji dokonał porównania rozprawki o Inflantach z innymi pracami na ten temat i zapowiedział wydanie zbioru podań łotewskich w opracowaniu Władysława Weryhy. Podania łotewskie tego ostatniego ukazały się w 1892 roku w Bibliotece „Wisły”. Tomik zawierał 32 thumaczone na język polski bajki zapisane od 3 informatorek i został pozytywnie odebrany przez krytykę, w tym wspomnianego Manteuffela ${ }^{23}$.

W wieku XX w związku z odzyskaniem przez Polskę niepodległości nastąpiła pewna zmiana w podejściu do folkloru łotewskiego i nie tylko do tej sfery s. 556

2 J. Karłowicz, Ostatnie prace o Inflantach, „Biblioteka Warszawska” 1892, t. 2, 23 H. Kapełuś, Folklor obcy w badaniach Polaków, s. 591. 
kultury ${ }^{24}$. Zaczęły powstawać bardziej obszerne artykuły poświęcone bajkom łotewskim, ale nadal niezbyt liczne. Julian Krzyżanowski opublikował kilka prac na ten temat, w tym Bajki w świetle najnowszych badañ ${ }^{25} \mathrm{w}$ „Warszawskim Dzienniku Narodowym" (z 4 października 1935 roku), prezentując w nim zakres działań łotewskich folklorystów. Odnotował między innymi fakt otwarcia w Rydze Państwowego Archiwum Folkloru (Folkloras krātuve), które do 1934 roku zgromadziło ponad 10 tys. rodzimych wariantów pieśni i ponad 50 tys. ludowych opowieści. Wiele miejsca poświęcił wzorowanej na fińskiej systematyce wątków 10-tomowej pracy Piotr Szmitsa (łot. Pēteris Šmits). Polski folklorysta wykazał bogactwo łotewskich wątków bajkowych, jak też znaczny ich związek z mitologią, co dowiódł na konkretnych przykładach $^{26}$.

Wedle najnowszych ustaleń właśnie kontakt Krzyżanowskiego z łotewskimi folklorystami (przebywał w latach 1930-1934 na Uniwersytecie Łotewskim w Rydze jako wykładowca literatur słowiańskich ${ }^{27}$ ) umożliwił badaczowi zapoznanie się z systematyką bajkowych wątków Aarnego i Thompsona, co sprawiło, że polski badacz rozpoczął pracę nad narodową wersją tego dzieła28. W tym kontekście rzec można, że gdyby nie łotewskie badania bajkoznawcze, a zwłaszcza dzieło Szmitsa, twórcy monumentalnej systematyki łotewskiej bajki ludowej pod tytułem Łotewskie bajki i podania (1925-1937, 25 tomów ${ }^{29}$, nie wiadomo, jak długo czekalibyśmy na Polska bajkę ludowa w układzie systematycznym, której pierwsza wersja powstała już w 1946 roku, a pełne, dwutomowe wydanie w latach 1962-1963.

24 Badacze mówią nawet o nowym otwarciu relacji między Polską a Łotwą, które odzyskały niepodległość w tygodniowym odstępie 11 listopada i 18 listopada 1918. Zob. M. Michaliszyn, Udział polskich naukowców w tworzeniu łotewskiego słownika konwersacji (zarys problematyki), „Przegląd Humanistyczny” 2015, nr 12, s. 153.

25 J. Krzyżanowski, Bajki w świetle najnowszych badań, „Warszawski Dziennik Narodowy”, 4 października 1935, R. 1, nr 130B, s. 4. Zob. tenże, Bajki łotewskie, „Komunikat Instytutu Bałtyckiego w Toruniu” 1935, nr 39; tenże, Podanie łotewskie w poezji polskiej, „Pion” 1936, nr 4(13), s. 4-5.

26 J. Krzyżanowski, Bajki w świetle najnowszych badań, s. 4.

27 M. Michaliszyn, Udziat polskich naukowców..., s. 153.

28 M. Michaliszyn, Wplyw totewskiej folklorystyki na ksztalt zainteresowań badawczych Juliana Krzyżanowskiego, „Prace Filologiczne. Literaturoznawstwo” 2017, nr 10, s. 131-140.

29 Tamże, s. 133. 
Krzyżanowski nie był jedynym polskim naukowcem przebywającym na Łotwie, który zainspirował się tamtejszymi badaniami folklorystycznymi ${ }^{30}$. W 1938 roku Stanisław Kolbuszewski, również goszczący w Rydze w roli wykładowcy (objął stanowisko po Krzyżanowskim) ${ }^{31}$, opublikował kilka prac na ten temat. W czasopiśmie „Jantar. Organ Instytutu Bałtyckiego. Przegląd kwartalny zagadnień naukowych pomorskich i bałtyckich ze szczególnym uwzględnieniem historii, geografii i ekonomii regionu bałtyckiego" [rok II, zeszyt 3 (7)] zamieścił na przykład artykuł Z przeszłości i historii i sztuki Łotwy, w którym jedną z niewielkich części poświęcił folklorowi i etnografii Łotyszy. Chociaż w swych rozważaniach skupił się bardziej na obrzędach i pieśniach niż bajkach, zwrócił uwagę na zauważalną w zachowanych tekstach oralnych trwałość wierzeń i tradycji silniejszą niż w przekazach odnotowanych w Polsce czy na Litwie, co pozwala na traktowanie ustnego folkloru jako ważnego świadectwa kulturowego ${ }^{32}$.

Wzrastająca fala zainteresowania kulturą Łotwy, w tym folklorem, została przerwana w wyniku wybuchu II wojny światowej, a okres po jej zakończeniu zdecydowanie nie sprzyjał poprawie sytuacji. W II połowie XX wieku, jako że Łotwa stała się jedną z republik radzieckich, kultura tego kraju została włączona w obszar szeroko pojętej kultury rosyjskiej i tak ją postrzegano w Polsce, o czym świadczą antologie baśni z tego czasu, na przykład Bajki ludów nadbaltyckich (1951) ${ }^{33}$, jak i naukowe opracowania. W 1962 roku wydano na przykład zbiór Literatura bursztynowego wybrzeża, w którym wspomniano o wadze ludowych opowieści łotewskich jako źródle literatury narodowej, ale nie rozwijano tego wątku, bowiem tematem głównym była szeroko pojęta

30 Zob. V. Vonogs, Z dziejów badań folklorystycznych $w$ Łatgalii [z j. łotewskiego przełożyli St. F. i J. Kolbuszewscy], „Literatura Ludowa” 1986, nr 4-6, s. 125-139.

31 M. Michaliszyn, Udziat polskich naukowców w tworzeniu totewskiego słownika konwersacji, s. 154; zob. taż, Pobyt Profesora Stanisława Kolbuszewskiego w Rydze na podstawie materiałów zachowanych w Państwowym Historycznym Archiwum Łotwy, „Baltica-Silesia” 2013, nr 1, s. 21-56.

32 J. Kolbuszewski, Z przeszłości i historii i sztuki Łotwy, „Jantar. Organ Instytutu Bałtyckiego. Przegląd kwartalny zagadnień naukowych pomorskich i bałtyckich ze szczególnym uwzględnieniem historii, geografii i ekonomii regionu bałtyckiego" 1938, r. II, z. 3, s. 182-183.

33 Bajki ludów nadbałtyckich, z ros. przeł. J. Kopciowa, red. K. Kuliczkowska, Warszawa 1951. 
twórczość nadbałtycka ${ }^{34}$. Z kolei pojawiające się sporadycznie w tym czasie recenzje poszczególnych tomów łotewskich baśni odnosiły się głównie do tłumaczeń rosyjskich, gdyż to język wschodnich sąsiadów był obowiązującym na Łotwie. I tak na przełomie 1964/1965 roku ukazała się na łamach „Ludu” (t. 50, s. 639-640) recenzja Kazimierza Pietkiewicza tomu pod tytułem Latyszskije narodnyje predanija (Izd. Akademii Nauk Latwijskoj SSR, Riga 1962. Tekstu str. 165, ilustr. 12. Wyboru tekstów dokonała A. Ancelane, przekładuM. Krupnikowa, rysowat art. plast. P. Szenhof, red. E. Sokot). Autor dokonał w niej prezentacji zawartości zbioru, podkreślając jego bogactwo: „Wybór podań ludu łotewskiego w języku rosyjskim, składający się z 317 pozycji, jest oparty na oryginalnych tekstach łotewskich, które zostały wydane w postaci zbiorku (752 poz.) w roku 1961”35, jednocześnie wyrażając żal, że został udostępniony w języku rosyjskim, co pozbawia go swoistego czaru oryginału. Z kolei w roku 1967 Pietkiewicz publikuje Etnografię Łotwy (Kultura materialna), w której badacz, koncentrując się na pozaduchowym wymiarze łotewskiej kultury, wspomina o jej zależności od obcych wpływów, w tym różnych religii, co miało znaleźć przełożenie na folklor ${ }^{36}$. Można sądzić, że miał na myśli wpływ rosyjski, chociaż zdecydowanie większy zakres odziaływania miała kultura niemiecka i protestantyzm. Podobne stanowisko dotyczące wpływów rosyjskich zdają się potwierdzać inne badania, na przykład bajek Rosjan łotewskich, którymi zajmował się Biełousow ${ }^{37}$.

Być może mówienie o bajkach łotewskich w Polsce w okresie powojennym bez odwołań do tradycji rosyjskiej nie było mile widziane, więc unikano poruszania tego typu tematyki ${ }^{38}$. W zasadzie do 1989 roku niewiele powstało prac dotyczących ludowych bajek łotewskich, poza przypomnieniem prac Ulanowskiej czy Weryhy w Dziejach folklorystyki polskiej39, jak też w przy-

34 Literatura bursztynowego wybrzeża, oprac. M. Warneńska, A. Galis, Warszawa 1962, s. 6 .

35 K. Pietkiewicz, Latyszskije narodnyje predanija (Izd. Akademii Nauk Latwijskoj SSR, Riga 1962. Tekstu str. 165, ilustr. 12. Wyboru tekstów dokonała A. Ancelane, przektadu-M. Krupnikowa, rysowat art. plast. P. Szenhof, red. E. Sokot), „Lud” 1964/1965, t. 50, s. 639-640.

36 K. Pietkiewicz, Etnografia Łotwy (kultura materialna), Wrocław 1967, s. 18.

37 A. F. Biełousow, Folkłor russkowo nasielenia pribaltyki, Moskwa 1976, s. 93.

38 D. Rembiszewska, dz. cyt., s. 102.

39 H. Kapełuś, dz. cyt., s. 590-591. 
gotowanym numerze specjalnym „Literatury Ludowej” poświęconym folklorowi łotewskiemu ${ }^{40}$. Po tym okresie, czemu towarzyszyła zmiana polityczna, sytuacja się poprawiła i w zasadzie sukcesywnie, ale oszczędnie, wydawane są prace na ten temat, chociaż bajki łotewskie częściej rozpatrywane są w kontekście szeroko pojętego folkloru europejskiego czy słowiańskiego niż jako odrębne dziedzictwo kulturowe. Nadal jednak zauważalna jest marginalizacja tego typu badań. Oprócz prac przywołanych już badaczy, zwłaszcza Andrzeja Rataja czy Doroty Rembiszewskiej, wspomnieć można o recenzjach publikacji dotyczących łotewskich wierzeń i zjawisk językowych, w obrębie których pojawiają się niekiedy rozważania o bajkowych czarownicach i diabłach ${ }^{41}$. Analizy wybranych wątków czy motywów z bajek łotewskich przywołuje w swych artykułach Justyna Prusinowska. W tekście o Śpiacych rycerzach w literaturze łotewskiej badaczka zajęła się znanym podaniem o rycerzach czekających w jaskini na znak, by się przebudzić i walczyć o ojczyznę, wykazując jego znikome występowanie na Łotwie. Odnotowała jedynie warianty w części Inflant Polskich, a więc na terenach zdominowanych przez polską i litewską szlachtę, co thumaczy występowanie tematyki rycerskiej ${ }^{42}$. W innym tekście badaczka poruszyła z kolei tematykę motywu kamieni w łotewskim folklorze ${ }^{43}$.

Przywołane badania odwołują się głównie do folklorystyki filologicznoantropologicznej, rzadziej proponują ujęcie komparatystyczne, a ono wydaje się zachęcające do dalszych dociekań. W jednym z artykułów z 2003 roku rozpatrywałam specyfikę ludowych baśni łotewskich w kontekście baśni bałtyckich, w tym polskich ${ }^{44}$. Przeprowadzone przeze mnie wstępne analizy

40 „Literatura Ludowa” 1986, nr 4-6.

41 B. Biesiadowska-Magdziarz, Benita Laumane, Jūra latviešu valodā un folklorāa: etnolingvistiskais aspekts (Morze w języku i folklorze totewskim: aspekt etnolingwistyczny), Liepājas Universitāte Kurzemes Humanitārais Institūts, Liepāja 2013, ss. 403, „Acta BalticoSlavica" 2013, t. 37, s. 617-619.

42 J. Prusinowska, Śpiacy rycerze w literaturze łotewskiej: Dusošie bruṇinieki latviešu literatūrā, „Baltica-Silesia” 2013, t. 1, nr 1, s. 91-125.

43 J. Prusinowska, Kamienne budowle, diabelskie sztuczki. Folklor łotewski $i$ „,Wieża siedmiu wodzów" Romana Zmorskiego, [w:] Kamień w literaturze, języku i kulturze, red. M. Roszczynialska, K. Wądolny-Tatar, Kraków 2013, s. 133-145; E. Stryczyńska-Hodyl, Diabet w literaturze litewskiej i łotewskiej od połowy XIX do połowy XX wieku, Poznań 2008.

44 V. Wróblewska, Ludowe baśnie totewskie w kontekście baśni battyckich, „Literatura Ludowa" 2003, t. 4-5, s. 33-40. 
pozwalają mówić o wspólnotowym charakterze bajek łotewskich w odniesieniu do bajek europejskich, w tym polskich, na co zresztą zwracało uwagę wielu innych badaczy. W łotewskim repertuarze spotykamy wszystkie znane wątki, jak T 480A „Dwie siostry, dobra i zła” oraz jej pochodne T $480 \mathrm{C}^{45}$, oraz popularne bajki o Jasiu i Małgosi (T 327A), w tym typy pokrewne T 327D „Czarownica ludożerczyni” i T 327E „Ucieczka od czarownicy”46, tyle że czarownica żyje w domku nie ze słodyczy, lecz w chatce, którego dach zrobiony jest z sera. Bliższe wpływom rosyjskim wydaje się obrazowanie samej postaci jędzy mającej żelazne zęby i krzywe drewniane nogi ${ }^{47}$. Jednak podobnie jak w polskich bajkach czarownice okazują się ludożerczyniami:

[...] wszędzie kiszki obmotane dokoła izby, wchodzi do izby i widzi, że w sionce, na drzwiach, na klamce, ludzka ręka, a na progu ludzka noga. Odmyka drzwi do izby, patrzy, że chrzestna matka je człowieka, już całego człowieka zjadła tylko głowa została się i ona je tę głowę ${ }^{48}$.

Dla porównania warto przywołać analogiczny fragment z zapisu Oskara Kolberga, co jedynie potwierdza wspólnotowość pewnej grupy demonologicznych wyobrażeń:

Dziewczyna patrzy, a tu zamiast zaporą, drzwi są ręką ludzką zaparte [...] ldzie znów dalej, a tu na kołku wisi głowa ludzka [...] Idzie dalej, a tu wisi takie długie lelito (jelita, kiszka) [...] Nareszcie zagląda do garka, a tam w tym garku stoji krew... (T 327D) ${ }^{49}$.

Wśród oryginalnych wyróżników opowieści łotewskich można wskazać łaźnię jako miejsce akcji. Jest to znany motyw kulturowy, z którym wiążą się liczne wierzenia i strategie lecznicze, co znajduje odbicie także w baśniach, ukazujących tego typu przestrzeń jako miejsce transformacji, walki z demonami

45 S. Ulanowska, Łotysze..., t. 18, s. 306-310, nr 26 oraz s. 311-313, nr 27 (T 480A); s. 313-315, nr 28 (T 480C).

46 Tamże, s. 316, nr 29.

47 Tamże, s. 407, $\mathrm{nr} 46$.

48 Tamże, s. 445, nr 51.

49 O. Kolberg, Dzieła wszystkie, Wrocław-Poznań 1962, s. 21-22. 
czy kontaktu ze zmarłymi ${ }^{50}$. Równie popularne w bajkach są motywy związane z kultem drzew i węży, łączonych $\mathrm{z}$ dawną religią Bałtów ${ }^{51}$, a o co miało być odnotowane już w zapisach uchwał synodowych prowincji ryskiej z 1428 roku oraz kroniki z 1611-1620 (wspomina o nich Łowmiański w swej pracy Elementy indoeuropejskie $w$ religii Battów $)^{52}$. Zarysowana jedynie tego rodzaju problematyka wymaga jednak głębszych analiz i interpretacji z uwzględnieniem zdecydowanie bogatszego zakresu materiału.

Powyższy przegląd folklorystycznych badań nad bajkami łotewskimi w naszym kraju pozwala stwierdzić, że nie doczekały się one gruntownego opracowania i edycji, która przybliżyłaby tę część folkloru polskim czytelnikom, nie licząc pochodzących z poprzednich okresów literacko opracowanych wersji adresowanych do dzieci, na przykład Piesek i kotek. Łotewskie bajki ludowe (1988), zawierający 5 bajek, Piekę piękne chlebusie. Bajka łotewska (1981), czy Bajki ludowe o zającu, lisie i innych zwierzętach (1991). Ta swoista marginalizacja, która zauważalna jest od XIX wieku, wynika co najmniej z kilka powodów. Podstawową barierą - poza powikłanymi losami obu narodów, w tym czynnikami politycznymi - jest łotewski język, mało w Polsce znany, a dostępne thumaczenia dawne i współczesne nie oddają specyfiki i różnorodności bajek Łotyszy. Ponadto przekłady dokonane przez Ulanowską czy Weryhę funkcjonują jako kompletne, więc może panować mylne przekonanie, że nie ma potrzeby tworzenia dodatkowych thumaczeń. Nie sprzyja poprawie tego stanu również powielana przez wielu etnografów, zwłaszcza na przełomie XIX i XX wieku, opinia na temat wtórności ludowych bajek łotewskich, mających kształtować się pod wpływem czynników obcych - niemieckich, polskich, rosyjskich, co zakłada niejako ich nieoryginalność. Wiadomo, że nie jest to prawdą, gdyż nawet zapożyczone wątki zyskują w lokalnym obiegu nowy kształt i wymiar semantyczny, czego dowodzą choćby bajki kaszubskie, rozwijające się pod niemałym wpływem niemieckim, a mimo to zachowujące swe niepowtarzalne piętno ${ }^{53}$.

50 V. Wróblewska, dz. cyt., s. 37.

51 Tamże, s. 39.

52 Tamże. Zob. T. Łowmiański, Elementy indoeuropejskie w religii Baltów, [w:] Ars historia, red. P. Biskup, Poznań 1976, s. 150-153.

53 Zob. V. Wróblewska, Bajka ludowa na Kaszubach, [w:] Słownik polskiej bajki ludowej, T. 1, red. V. Wróblewska, Toruń 2018, s. 99-100. 
Powyższe tendencje wyrastają z ogólnego małego zainteresowania Polaków Łotwą i jej kulturą, być może za bardzo kojarzonych z dawnym systemem komunistycznym wprowadzonym przez ZSRR, o którym wielu naszych rodaków chce zapomnieć. Przede wszystkim jednak należałoby ten stan tłumaczyć zauważalnym nie tylko w Polsce zwrotem ku amerykańskiej kulturze popularnej, która wyznacza i narzuca, za sprawą mediów, określone wzorce kulturowe, w tym upodobania estetyczne odnoszące się do baśni. W związku z tą tendencją tradycyjny folklor, nie tylko łotewski, jako mało atrakcyjny nie cieszy się uznaniem odbiorców, co przekłada się na równie nieznaczne zainteresowanie badaczy.

\section{Bibliografia}

[b.a.], Dusza, [hasło w:] Wielka encyklopedya powszechna ilustrowana, red. Sz. Askenazy, T. 17-18, Warszawa 1896.

Bajki ludów nadbałtyckich, przeł. Kopciowa, red. K. Kuliczkowska, Warszawa 1951.

Biełousow A. F., Folkłor russkowo nasielenia pribałtyki, Moskwa 1976.

Biesiadowska-Magdziarz B., Benita Laumane, Jūra latviešu valodā un folklorā: etnolingvistiskais aspekts (Morze w języku i folklorze łotewskim: aspekt etnolingwistyczny), Liepājas Universitāte Kurzemes Humanitārais Institūts, Liepāja 2013, ss. 403, „Acta Baltico-Slawica” 2013, t. 37.

Kapełuś H., Folklor obcy w badaniach Polaków, [w:] Dzieje folklorystyki polskiej 1864-1918, red. H. Kapełuś, J. Krzyżanowski, Warszawa 1982.

Karłowicz J., Ostatnie prace o Inflantach, „Biblioteka Warszawska” 1892, T. 2.

Kolberg O., Dzieła wszystkie, Wrocław - Poznań 1962.

Kolbuszewski J., Z przeszłości i historii i sztuki Łotwy, „Jantar. Organ Instytutu Bałtyckiego. Przegląd kwartalny zagadnień naukowych pomorskich i bałtyckich ze szczególnym uwzględnieniem historii, geografii i ekonomii regionu bałtyckiego" 1938, r. II, z. 3.

Krzyżanowski J., Bajki łotewskie, „Komunikat Instytutu Bałtyckiego w Toruniu” 1935, nr 39; Podanie łotewskie w poezji polskiej, „Pion” 1936, nr 4 (13).

Krzyżanowski J., Bajki w świetle najnowszych badań, „Warszawski Dziennik Narodowy", 4 października 1935, R. 1, nr 130B, s. 4. 
Literatura bursztynowego wybrzeża, oprac. M. Warneńska, A. Galis, Warszawa 1962.

Łowmiański T., Elementy indoeuropejskie w religii Bałtów, [w:] Ars historia, red. P. Biskup, Poznań 1976.

Manteuffel G., Ulanowska Stefania: Łotysze Inflant polskich, a w szczególności z gminy wielońskiej powiatu rzeżyckiego, obraz etnograficzny. Zbiór wiad. Do antropologii krajowej, t. XV, str. 181-282, Kraków 1891, s. 591-592, „Kwartalnik Historyczny" 1892, t. 6.

Michaliszyn M., Pobyt Profesora Stanisława Kolbuszewskiego w Rydze na podstawie materiałów zachowanych w Państwowym Historycznym Archiwum Łotwy, "Baltica-Silesia" 2013, nr 1.

Michaliszyn M., Udział polskich naukowców w tworzeniu łotewskiego słownika konwersacji (zarys problematyki), „Przegląd Humanistyczny” 2015, nr 12.

Michaliszyn M., Wpływ łotewskiej folklorystyki na kształt zainteresowań badawczych Juliana Krzyżanowskiego, „Prace Filologiczne. Literaturoznawstwo” 2017, $\mathrm{nr} 10$.

Pietkiewicz K., Etnografia Łotwy (kultura materialna), Wrocław 1967.

Pietkiewicz K., Latyszskije narodnyje predanija (Izd. Akademii Nauk Latwijskoj SSR, Riga 1962. Tekstu str. 165, ilustr. 12. Wyboru tekstów dokonała A. Ancelane, przekładu - M. Krupnikowa, rysował art. plast. P. Szenhof, red. E. Sokoł), "Lud” 1964/1965, t. 50.

Podziewska L., Ludowe opowiadania komiczne. Poetyka i antropologia, Wrocław 2010.

Prusinowska J., Kamienne budowle, diabelskie sztuczki. Folklor łotewski i „Wieża siedmiu wodzów" Romana Zmorskiego, [w:] Kamień w literaturze, języku i kulturze, red. M. Roszczynialska, K. Wądolny-Tatar, Kraków 2013.

Prusinowska J., Śpiący rycerze w literaturze łotewskiej: Dusošie bruṇinieki latviešu literatūrā, „Baltica-Silesia” 2013, T. 1, nr 1.

Rataj A., Stefania Ulanowska. Tajemniczy życiorys. Niepublikowane fragmenty twórczości, Białystok 2016.

Rembiszewska D., XIX-wieczne badania ludoznawcze na obszarze Łotwy w świetle korespondencji Stefanii Ulanowskiej do Jana Karłowicza, „Acta Baltico-Slavica” 2014, t. 38.

Stryczyńska-Hodyl E., Diabeł w literaturze litewskiej $i$ łotewskiej od połowy XIX do połowy XX wieku, Poznań 2008. 
Ulanowska S., Łotysze Inflant Polskich a w szczególności gminy wielońskiej, powiatu rzeżyckiego: obraz etnograficzny, „Zbiór Wiadomości do Antropologii Krajowej" 1891, T. 15, cz. 1.

Vonogs V., Z dziejów badań folklorystycznych w Łatgalii [z j. łotewskiego przełożyli St. F. i J. Kolbuszewscy], „Literatura Ludowa” 1986, nr 4-6.

Wężowicz-Ziółkowska D., Miłość ludowa. Wzory miłości wieśniaczej w polskiej pieśni ludowej XVIII-XX wieku, Wrocław 1991.

„Wisła" 1888, T. 2, z. 1.

Wróblewska V., Bajka ludowa na Kaszubach, [w:] Słownik polskiej bajki ludowej, T. 1, red. V. Wróblewska, Toruń 2018.

Wróblewska V., Ludowe baśnie łotewskie w kontekście baśni bałtyckich, „Literatura Ludowa" 2003, T. 4-5. 